\title{
STRATIGRAPHIC INTERPLAYS BETWEEN IGNEOUS AND SEDIMENTARY EVENTS IN THE EARLY PALAEOZOIC JAIBARAS TROUGH (NORTHEAST BRAZIL)
}

\section{DIÓGENES CUSTODIO DE OLIVEIRA}

\begin{abstract}
The Jaibaras Trough is an example of an intraplate province for which both origin of magmatic manifestations and basin generation mechanisms are coeval. The magmatic suites demonstrate closed spatial and temporal relationships and, in turn, appear to be genetically associated. The simple distribution of igneous bodies occurrence constrains the spatial relationship between the whole magmatic activity during the basin infill. Sequential stratigraphic interplays between sediments and magmatic activities are perfectly constrained through thermal-structural features such as contact aureoles, faulted contacts/abutting and cross-cutting. The basin infill congregates continental immature siliciclastic sedimentary deposits. Deposition took place in areas of instable young shoulder relief and problably totals up to $3 \mathrm{~km}$ in thickness. Marked variations in thickness, rapid changes in depositional facies, interbedded thick conglomerates, local unconformities and disconformities of variable extent typify the overall sedimentary deposits making a regional palaeogeographic reconstruction difficult. Probably axial basin filling provided the sedimentation of shale and sandstone, whereas the rift flanks laterally sustained the alluvial fan conglomerates. The magmatic evolution of Jaibaras Trough comprises basically four temporal and spatially separated phases. The early phase involved the Vendian Coreau Dike Swarm, and represents the initial tectonic pulse of rift opening. With continued breakup, reactivation of deeper shear zones gave rise to the emplacement of the Mucambo Pluton during Early Cambrian times, which preceeded the main rift infill. The basin sedimentation was accompanied by a huge volume of volcanism, most of which is composed by flood basalts, dikes and sills. The Meruoca Pluton is the last basin-related igneous manifestation during the Upper Cambrian.
\end{abstract}

Keywords: Jaibaras Trough, Borborema Province, Igneous-Sedimentary Sequence, Tectono-Stratigraphic Evolution, Basin Infill

INTRODUCTION The Jaibaras Trough (JT), the most important, prominent and extensive exposure of Early Paleozoic sedimentary sequences in a wide Brasiliano-age area, including the Borborema Province and the Nigerian Shield, is an example of an intraplate province for which both origin of magmatic manifestations and basin generation mechanisms are coeval. Whether or not the magmatism is the result of basin formation mechanisms or vice-et-versa is difficult to constrain. Despite all uncertainties involved in the magmasedimentation system, the most obvious and reasonable seems to be an integrated process. The magmatic suites mainly constitute the exposed floor of a continental rift flank and thus, combined with sedimentary rocks, provides an opportunity to integrate igneous thermo-tectonic approaches within a geodynamic evolution of an extensional regime.

It extends as a well-defined narrow depression (dimensions of 10$20 \mathrm{~km}$ in width $\mathrm{x} 120 \mathrm{~km}$ in length) overlying gneisses, migmatites and earlier metasedimentary terrains of the basement (Fig. 1). The main graben is bordered by mylonitic shear zones reactivated normally inside the continental-scale Transbrasiliano Lineament. This grabenlike feature is the result of a strong and widespread continental breakup that took place during the separation of Laurentia and Baltica from Western Gondwana (Dalziel 1997). Resultant reactivation adjustments are observed globally along regional lithospheric anisotropies, in general generating rifts which did not evolve to a passive margin basin.

In this paper we integrate all geological observations in order to explain and establish a plausible stratigraphic model, where the role of magmatic expressions are primarily explored. The approach used to generate this framework was based on field studies and on a compilation of available data.

\section{REGIONAL BASEMENT SETTING}

The so called Northwestern Ceará Domain, which encompasses the JT (Fig. 1), is a triangle-shaped, highly deformed and sheared wedge, lying at the extreme northwest of the Borborema Province. This domain configures a geometrical array of horsts and grabens aligned NE-SW and juxtaposed by deep subvertical shear zones, named the Transbrasiliano Lineament. The structural highs, called Migmatitic-Gneiss Complex, consists of Archean to Paleoproterozoic high-grade rocks (in general granulites and charnockites) strongly reworked during the Brasiliano Orogeny. The grabens are generally filled by conglomerates, sandstones, limestones and shales as well as by volcanogenic intrusions and extrusions, all metamorphased in low-temperature facies. A detailed compilation concerning the geology of Northwestern Ceará domain is available in Torquato \& Nogueira Neto (1996).

Two kinds of graben fill, displaying contrasting tectonic evolution may be distinguished in the Northwestern Ceará domain (Jardim de Sa 1994, Torquato \& Nogueira Neto 1996): the first corresponds to the polycyclic ones, which were affected by the Transamazonico tectonothermal event $(1.8 / 2.2 \mathrm{Ga})$ and were later reworked by the Brasiliano deformational event $(0.5 / 0.7 \mathrm{Ga})$. Associated to these polycyclic sequences, docked onto basement highs, large thrust and ramps of

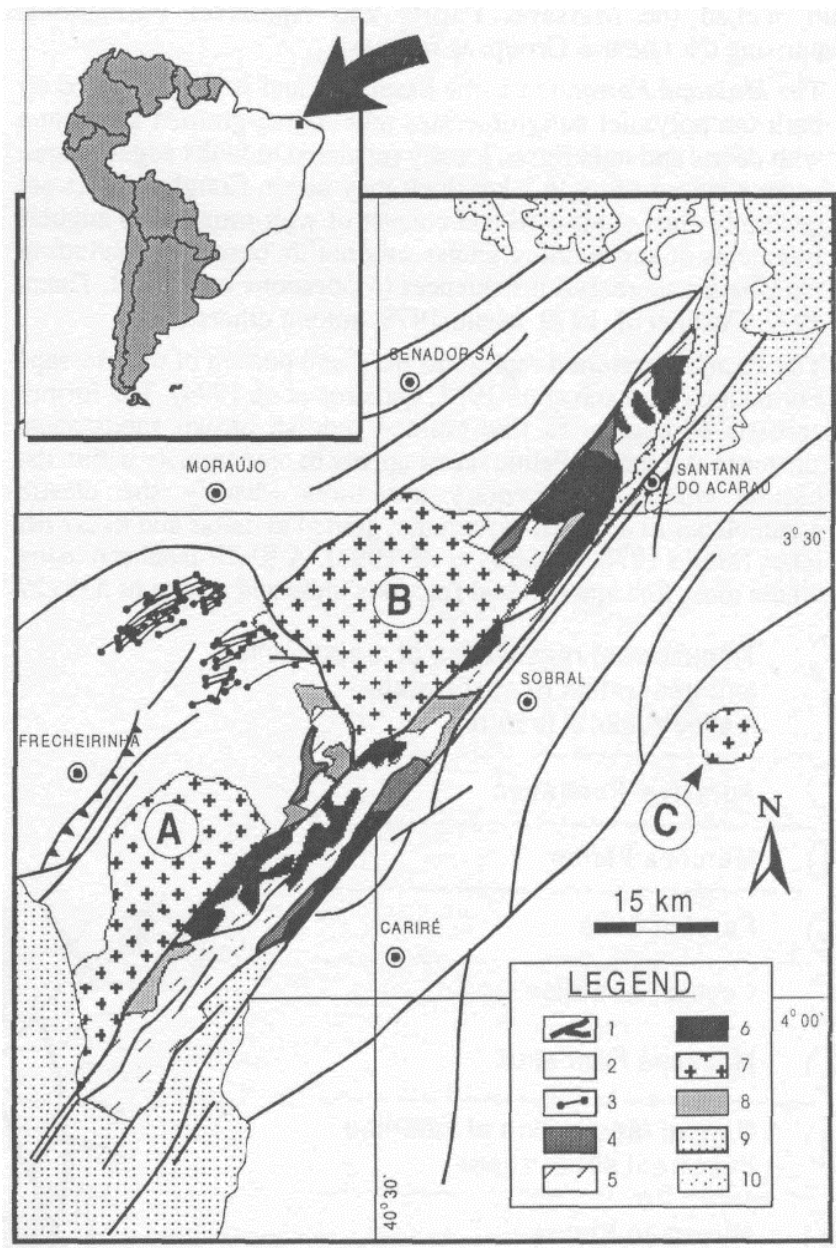

Figure 1 - Geologic map of the Jaibaras Trough showing the magmatic and sedimentary events (modified after Costa et al. 1979, Jardim de Sd et al. 1979, Cavalcante et al., 1983). Legend: (1) fault/shear zones; (2) supracrustal metasediments and gneiss-migmatitic basement; (3) Coreau Dike Swarm; (4) Massapê Formation; (5) Pacujd Formation; (6) Parapui magmatic event; (7) anorogenic granitoids, $A=$ Mucambo Pluton, $B=$ Meruoca Pluton, $C$ - Serra da Barriga Stock; (8) Aprazivel Formation; (9) Silurian-Devonian sediments of Parnaiba Basin; (10) Cenozoic covers. 
quartzites and schists also occur showing a highly complex tectonometamorphic evolution (Oliveira 1992, Torquato \& Nogueira Neto 1996). In contrast, the monocycle belts were only structured during the Brasiliano event. The Martinópole and Ubajara groups are the main representatives of this phase. Because of their excellent preservation within troughs, such units most likely correspond to an ancient preserved sedimentary basin, where the sediments of Martinopole Group characterize a typical rift infill whereas the Ubaraja Group represents a possible continental margin composed of weakly metamorphosed assemblages of sandstones with subordinate shales, overlain by a carbonate sequence (Hackspacher et al. 1988).

A complex array of arcuate, anastomosing, transcurrent shear zones play an important role in separating lithostructural blocks, in controlling the arrangement of supracrustal metasediments, and in the emplacement of granitic plutons.

\section{JAIBARAS TECTONOSTRATIGRAPHIC FRAMEWORK}

Basin Infill In general, it consists of continental immature siliciclastic sediments deposited in areas of unstable shoulder relief and probably totals up to $3 \mathrm{~km}$ in thickness. The complete sedimentary record indicates that the syn-tectonic activity decreases upwards. There is no clear evidence of regional metamorphism. However, anchimetamorphic mineralogy is widely recognized in the basin (Mello 1978, Novais et al. 1979). Despite the problematic reconaissance of lithostratigraphic successions in the JT, Costa et al. (1979) proposed to divide the entire sedimentary column into three units named the Massapê, Pacujá and Aprazivel Formations, comprising the Jaibaras Group, as follows:

a) The Massape Formation is the basal unit and is characterized by both fan polymict conglomerates and coarse-grained sandstone with debris and mud flows, locally restricted to faults edges, where accumulations of up to $2 \mathrm{~km}$ thick may occur. Conglomerates are generally clast-supported and consist of well-rounded to angular fragments of surrounding gneiss-migmatitic basement, including the Ubajara supracrustal sequences (Mabesoone et al. 1971, Danni 1972, Costa et al. 1979, Mello 1978, among others);

b) The Pacujá Formation represents the distal portion of the Massapê Formation (Gorayeb et al. 1988, Quadros et al. 1994). The former consists of coarse- to fine-grained reddish brown sandstones, siltstones and shales. Pelitic facies appear to predominate within the basinal center. Sedimentary structures identify the clastic assemblages as a fluvial system that graded to deltas and likely rift lakes (Mello 1978, Quadros et al. 1994). A Rb/Sr isochron using whole rock, fine and residual fractions indicated an age of $535 \pm 27$
Ma. for this deposit, which possibly represents either the age of deposition or anchimetamorphism (Novais et al 1979);

c) The upper sequence of polymitic conglomerates, named the Aprazivel Formation, differs from basal conglomerates by the presence of clasts of plutonic-volcanic rocks from Mucambo/ Meruoca plutons, Parapuí Suite and Massapê and Pacujá underlying sedimentary formations. Despite the change in clast composition, the Aprazivel Fm. presents a lot of similarities with the Massapê Formation in terms of sedimentary environments and tectonic controls.

Magmatic Activity Intrusives (Coreau Dike Swarm, Meruoca and Mucambo Plutons) and extrusives (sills and dikes of Parapuí Suite) demonstrate close temporal and spatial (Figs. 1 and 2) relationships with the JT, and hence, appear to be genetically related to its intrinsic tectonic evolution:

a) The Coreau Dike Swarm is characterized by a parallel and subvertical set of ENE-WSW trending dikes, which preferentially cross-cut metasediments of the Ubajara Group outcropping in the homonymous graben near the Meruoca Pluton, westward of the JT (Fig. 1). Petrographically, they comprise microgranite and rhyolite/ dacite with porphyritic textures. The combined ages give an average that fits well with the transition between the Proterozoic and the Phanerozoic, and clearly preceed the JT infill (Fig. 3);

b) The Mucambo Pluton occupies an area of about $200 \mathrm{~km}^{2}$ in the southwestern segment of the trough (Fig. 1). The pluton contact with surrounding host rocks is sharp and discordant. It is marked, to the west, by developed contact aureoles and chilled margins with metasediments of Ubajara Graben, reaching up to $2 \mathrm{~km}$ in width. In contrast, the contact to the east, with the Jaibaras Group, is faulted without evidence of contact metamorphism;

c) Meruoca is the northernmost pluton of the two intrusions (Fig. 1). It has a grossly square shape comprising an area of circa $400 \mathrm{~km}^{2}$. Its contacts are mainly given by faults and shear zones, in places developing aureoles with host-rocks. Petrographic analysis reveals a coarse to fine-grained facies containing fayalite, K-feldspar, biotite and hornblende;

d)The volcanic rocks of the Parapui Suite crop out as flood basalts, locally attaining $350 \mathrm{~m}$ in thickness, or as dikes with no preferential orientation and sills interbededed with siliciclastic sediments of the Massapê and Pacujá formations (Figs. 1 and 2), which locally comprise, in association with volcaniclastics rocks, a typical volcanosedimentary sequence (Quadros et al. 1994, Correa 1997). Based on

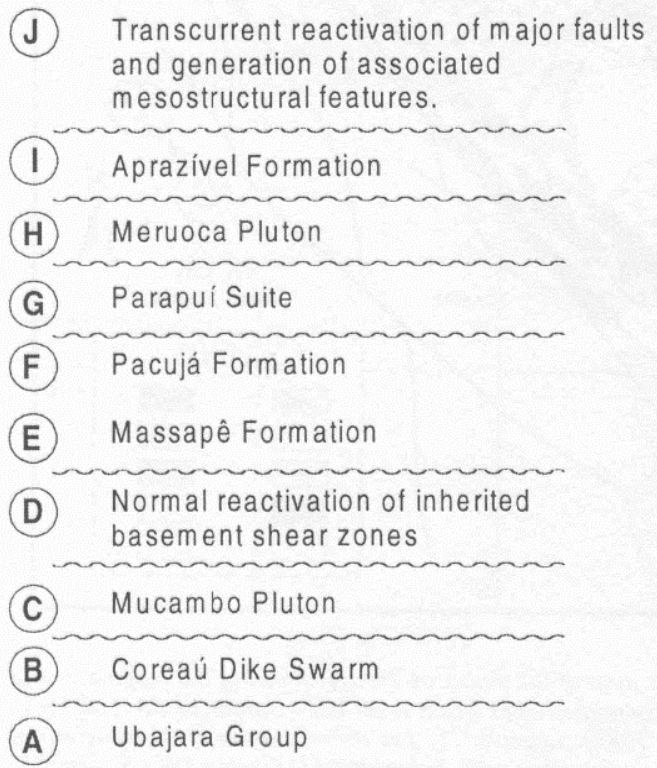

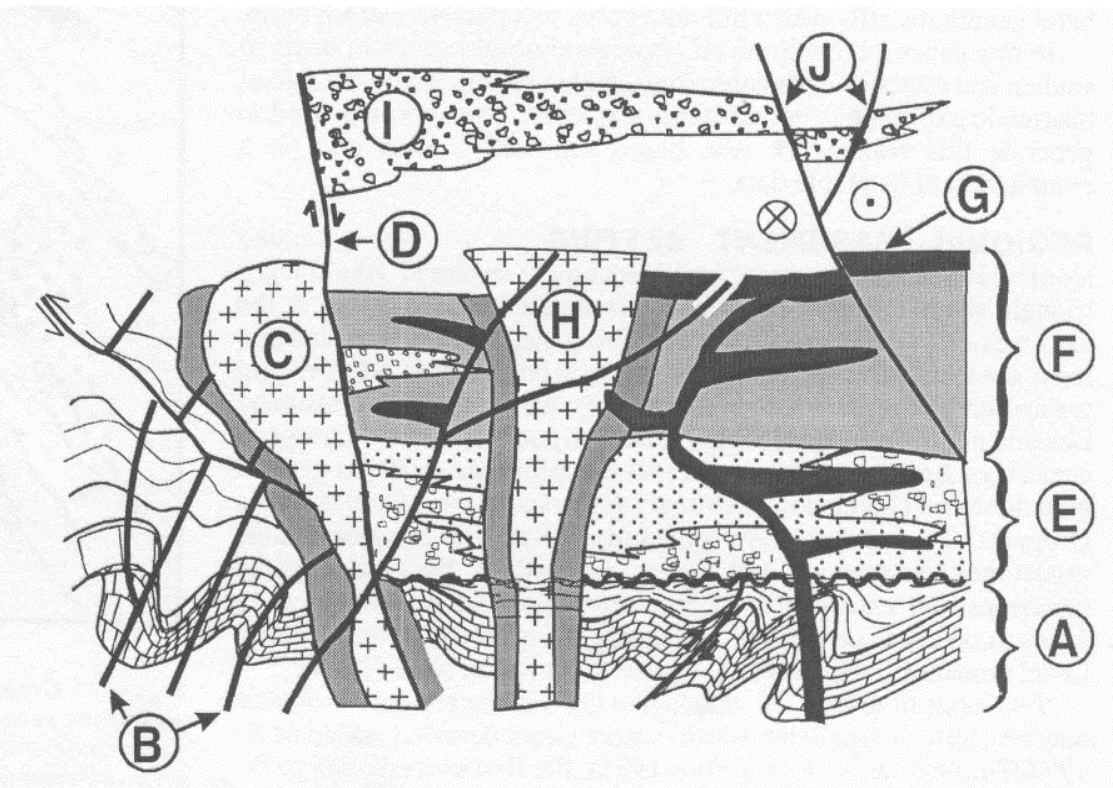

Contact aureoles and/or chilled margins

Figure 2 - Summarized schematic section showing the Jaibaras Trough tectonostratigraphic interactions between magmatism and sedimentary infill. Instead of displaying the configuration of igneous/sedimentary bodies, this sketch has solely the purpose of showing the stratigraphic interplays among the Jaibaras component units. All these schematic relationships are based on the compilation of available published data and as documented in surface exposures. 


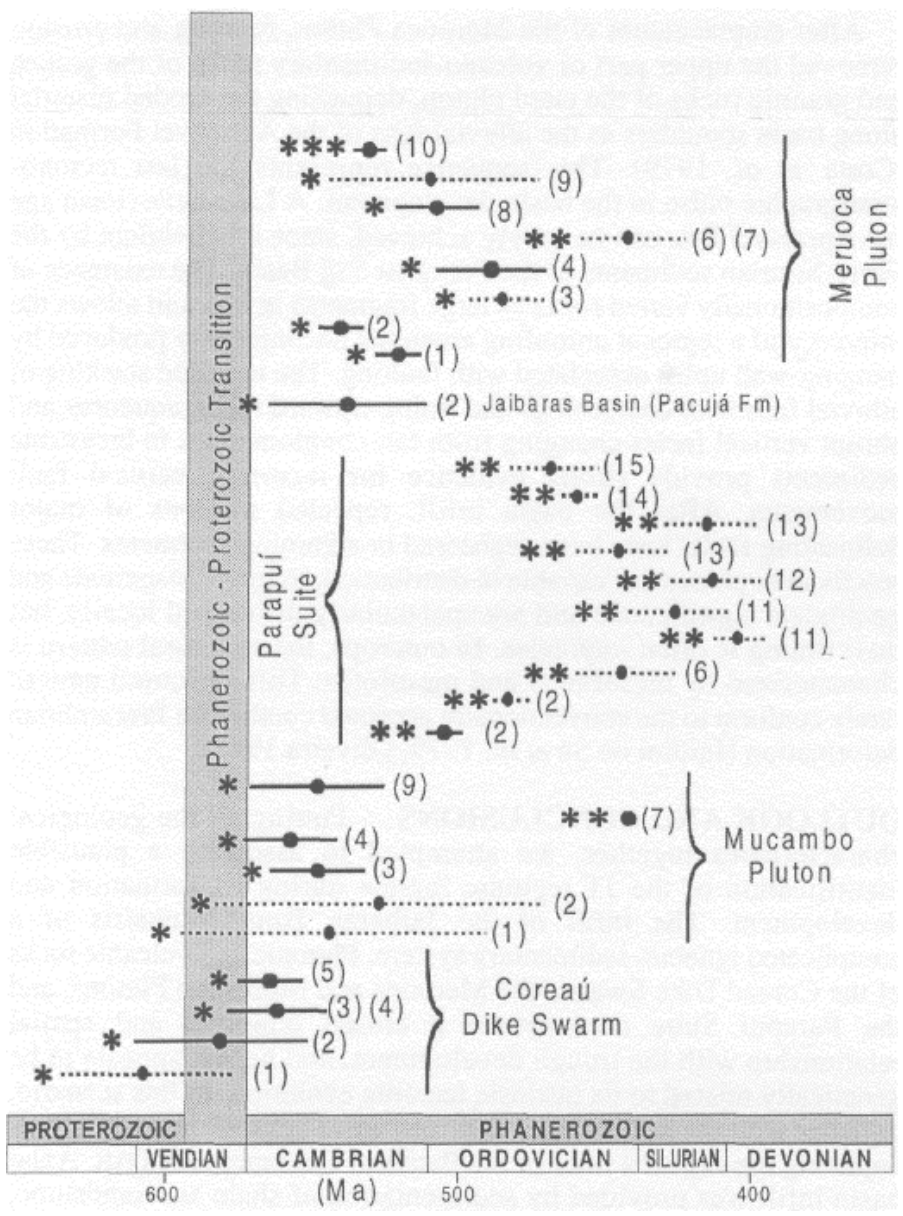

Figure 3 - Sketch illustrating all available radio me trie ages for the igneoussedimentary system in Jaibaras Trough. The full lines are considered as good dating results, whereas the dotted ones correspond to problematic and/or discutible ages. The dating range was squematized in average and its correspondent standard deviation. The geological time table is in accordance with Harland et al. (1990). Legend: The stippled band indicate the Proterozoic-Phanerozoic boundary according to Cowie (1981); (*) Rb-Sr ages; (**) K-Ar ages; (***) U-Pb ages. Bracketed numbers correspond to the cited references, (1) Brito Neves et al. (1978), (2) Novais et al. (1979), (3) Sial \& Long (1987), (4) Sial (1989), (5) Tavares Jr. et al. (1990), (6) Almeida et al. (1968), (7) Vandoros \& Oliveira (1968, quoted in Gomes et al. 1981), (8) B.B. Brito Neves (quoted in Jardim de Sd et al. 1979), (9) Sial et al. (1981), (10) Fetter et al., (1997), (11) Vandoros (1968), (12) P. Vandoros (quoted in Brito Neves et al. 1974), (13) Brito Neves et al. (1974), (14) Prado et al. (1981), (15) Mizusaki \& Saracchini (1990).

field mapping, Jardim de Sá et al. (1979) and Nascimento \& Gava (1979) recognize a recurrent behaviour of igneous activity, not only during basin infill (see also Nascimento et al. 1981, Gorayeb et al. 1988), but also after sedimentation, complicating their absolute stratigraphic position inside the trough. In general, $\mathrm{K} / \mathrm{Ar}$ geochronological determinations has shown a problematic age for the Parapuí Suite (Fig. 3). Petrographic description classifies the Parapuí rocks as andesite, rhyolite, syenite, andesine basalts, dolerite and volcaniclastics, in general presenting varied degrees of alteration.

\section{STRATIGRAPHIC INTERACTIONS BETWEEN SEDIMEN-} TARY SUCCESSIONS AND IGNEOUS EVENTS The first stratigraphic approach considering interactions between magmatism and sediments in the JT was published by Costa et al. (1979). Others studies followed basically the same focus, sometimes confirming, or with few changes, the previous column. The study of the tectonostratigraphic relations of the igneous-sedimentary system in the JT plays an important role in understanding the regional geodynamic evolution during the Borborema Province Proterozoic-Phanerozoic transition, providing insights into thermodynamic lithosphere structure (Oliveira, 2000). Despite the scarcity of direct observable stratigraphic interplays among sedimentary units and magmatic events (mainly owing to the lack of deep wells and seismic surveys within the JT), a compatible relative stratigraphic hypothesis can be constructed, as illustrated in Figure 2. Here, particular attention was paid to radiometric ages and classical structural associations, such as abutment and cross-cutting relationships.

Regionally, one can easily observes the existence of metasediments filling another trough adjoining to the JT, which is named the Ubajara Graben. The latter is a Neoproterozoic basin, which was submitted to a regional, the Brasiliano tectono-thermal event, and exhibit a compatible low P-T pattern represented by a well-developed slaty cleavage in a metamorphic greenschist facies (see Torquato \& Nogueira Neto 1995, for more a detailed description). The metasediments of the Ubajara Group originally formed a wide epicontinental basin, which was preserved from exhumation by mechanical subsidence probably during the JT rifting sorting process. These well-preserved grabens constrain the genetic lithostructural relationships between basement and sedimentary covers.

There is no evidence that continuous pervasive structural features, such as foliation, have affected the Jaibaras sequences. The slaty cleavage present in the Ubajara Group is truncated and/or is cross-cut, at high angle, by igneous bodies of the Coreau Dike Swarm. Mabesoone et al. (1971) and Sial (1989) reported the existence of dark sandstone xenoliths (possibly Ubajara Group) within the dikes. According to these reported arguments, there is a clear incompatible origin between the Brasiliano events and the JT evolution.

Geochronological evidences indicate that the first manifestation of the JT tectonism is the emplacement of the Coreau Dike Swarm which precedes the basin infill by ca. 40-50 Ma (Fig. 3). An interesting aspect is that the dike swarm displays a restricted occurrence cross-cutting foliated host rocks of the Ubajara Group. There is no evidence that these dikes truncated another JT igneous bodies anywhere else. Mafic xenoliths were described locally by Mabesoone et al. (1971) and Sial (1989) in some dikes, however the source of these xenoliths remains unknown. There is no evolved regional thermal event associated with the dike swarm, and then, as being essentially extensional in origin, the dike intrusion did not induce deformational or thermal effects when it segregated into shallow crustal level. Hackspacher et al. (1988) recognized some ductile deformational features in localized dikes, such as a kind of mylonitic foliation, which could strongly favored the line of evidence that is the record of Jaibaras rift tectonism.

Two points must be emphasized: (1) the lack of pervasive host rock deformational pattern within the Coreau dikes, reflecting a postBrasiliano evolution; and, (2) the fact that dike intrusions show no evidence of affecting the Jaibaras sediments and/or the subsequent magmatic activity. These arguments together with geochronological data bear out the interpretation that these dikes represented the first pulse of the JT tectonic evolution.

After dike swarm emplacement, the progressive increment of extensional stresses along preexisting, deep NE-SW shear zones created space at deep crustal levels that was passively filled by the Mucambo Pluton. At shallow levels, the pluton emplacement was accompanied by contact metamorphism and probably regional deformation within the Ubajara Graben (Fig. 2). Such emplacement level is in agreement with the abundant presence of compositionally varied xenoliths of horst rocks (Sial 1989). The more older stratigraphic linkage with JT can be interpreted from the contact with the sedimentary sequence, which is marked, along east side, by a strong normal-fault withou thermal effects. The metamorphic contact is well-developed along the entire western Mucambo boundary with Ubajara Group, ranging between two and three kilometers in width. The mineral assemblage points to a pyroxene-hornfels facies in the internal zone, where thermal aureole that overprint bedding and foliation of Ubajara Group can be observed (Costa et al. 1979, Nascimento et al. 1981). On the other hand, the external sector is composed of quartz-albite-chlorite-muscovite-biotite-epidote. Chilled margins are also found surrounding the granitic body, and kinematic indicators are not easily noted. The characteristics pointed out above fit well with a prototypical thermal aureole (as in Paterson \& Vernon 1995) which is not only the result of thermal effects but also constrains the strain regime of high shortening rates, the high-viscosity media and the shallow depth of intrusion.

The fact that the Mucambo Pluton only presents thermal aureole along the contact with the Ubajara Group is particularly important because is a direct indication that the pluton is stratigraphicaly older than the JT sedimentary sequences and the Meruoca Pluton. This 
timing relationship is corroborated by geochronological data (Fig. 3). Another additional important interpretation can be easily achieved: the lack of thermal effect resulting from the ascension and emplacement of the Mucambo Pluton along the boundary with the shear zone-fault indicates that the pluton was separated by a strong lateral and/or vertical fault offset which took place long time after its intrusion. In field mapping of the Ubajara Graben, Hackspacher et al. (1988) recognized thrust faults and associated, kilometric-scale, recumbent folds with westward vergence. The association of this pattern of thrusted structures with pluton space requirement is quite plausible during its emplacement processes. Nevertheless, the effective genetic relationship between these two factors remains to be better explained.

Another attractive tectono-stratigraphic relationship is shown between the country-rock and the Meruoca Pluton. The Pluton is almost entirely fault bounded. Contrary to the Mucambo Pluton, where the contact aureole found early along its boundary with the Ubajara Group, the Meruoca granite developed contact metamorphism along its whole boundary, including the sediments of the JT (Gorayeb et al. 1988). This metamorphism was able to produce high-temperature minerals such as garnet and diopside in the internal zone. Additionally at western border Ubajara Group sandstone and limestone xenoliths occur highly metamorphosed (Sial et al. 1981, Nascimento et al. 1981, Gorayeb et al. 1988, Sial 1989), invoking an younger age for the pluton. $\mathrm{Rb}-\mathrm{Sr}$ and $\mathrm{K}-\mathrm{Ar}$ geochronological data indicate that the emplacement of the Meruoca Pluton took place about 20-30 Ma after Mucambo Pluton.

The existence of a thermal aureole of the Meruoca Pluton in both Ubajara e Jaibaras units and the seletive existence of the Mucambo Pluton aureole affecting only rocks of Ubajara Group are crucial indications of the age of the latter group, apparently an intermediate age between the two plutons. This indirect stratigraphic relationship is partially corroborated by radiometric ages (Fig. 3). If the above stratigraphic interelationship is correct, the Jaibaras sediments were deposited during the Early-Middle Cambrian between the emplacement of Mucambo and Meruoca plutons (from 550-540 to 520-510 Ma). Novais et al. (1979) analysed non-thermally affected argillaceous rocks of the Jaibaras Group and obtained a $\mathrm{Rb}-\mathrm{Sr}$ isochron of $535 \pm 27 \mathrm{Ma}$ with seven samples, including whole rock, mudstones and residual fractions. This radiometric result, coupled with illite diffractometric data, were interpreted by the authors as anchimetamorphic age. This age seems to be well-constrained in terms of the stratigraphic interactions discussed previously.

Considering the basin infill, there is a complex stratigraphic relationship between the Parapuí Suite and the sediments. The Parapui igneous bodies occur as dikes, sills and perhaps lava flows. Despite all the difficulties in recognizing cross-cutting relationships in the inner JT, most studies consider the Parapuí Suite as completely post-basin infill (Danni 1972, Costa et al. 1979), pre-basin infill (Nascimento \& Gava 1979, Nascimento et al. 1981) or as several interbedded intercalations following the basin subsidence, in others words, syndepositional (Jardim de Sa et al. 1979, Gorayeb et al. 1988). Because of the existence of subordinate volcaniclastic rocks filling the basin (Quadros et al. 1994, Correa 1997) the syndepositional hypothesis seems to be more likely. Assuming that the Meruoca Pluton is younger than the Jaibaras Group, the Parapuí Suite could be considered older than that pluton. An important doubt is the stratigraphic position of the Jaibaras Group in this scenario. However, since it was considered coeval with the Parapuí Suite, one can ascribe the same age to the graben infill, which was also a question indirectly discussed early.
After emplacement of the Meruoca Pluton, faulting and erosion removed the upper part of volcano-sedimentary rocks of the graben and granitic rocks of the cited pluton, depositing the eroded material along basin shoulders as the alluvial fans of the Aprazivel Formation (Costa et al. 1979). This sequence represents the last tectonostratigraphic pulse in the basin development. A Late-Ordovician age for Aprazível Fm. can be easyly achieved, since it is overlain by the Early-Silurian sediments of the Parnaíba Sag Basin. The existence of compositionally varied rocks as large fragments in this unit allows the inference of a regional unroofing erosional unconformity produced by hanging-wall uplift associated with faulting. The repeated stacking of alluvial fans with coarsening- and fining-upward megasequences and abrupt vertical facies changing from fan-conglomerates to lacustrine sediments provide strong evidence for recurrent vertical fault movements. After the basin infill, repeated motions of major delineating faults have been registered in adjoining sediments. These reactivation phases are variable in distribution, in throw magnitude and geological significance and are spetacularly developed locally, but their timing is often imprecise. In outcrops, the structural pattern is characterized by mesofaults and mesofolds. This structural pattern rarely conform to the conventionally accepted continuous Precambrian deformation (Jardim de Sa et al. 1979, Oliveira 1992).

OUTLOOK AND CONCLUSIONS Putting all the geological characteristics together, we attempted to assemble a plausible identification of the JT tectonic regime during its formation and development. The infill of the Jaibaras Trough consists of a complicated igneous-sedimentary system. Plutonic and volcanic rocks of the Coreau Dike Swarm, the Meruoca and Mucambo Plutons, and the Parapuí Suite demonstrate a closed temporal and spatial relationship with the trough development, and hence, appears to be genetically related to its intrinsic tectonic evolution. In this scenario, together with the sedimentary deposits, there are four igneous events depicting the exposed floor of the flanks of this continental rift. Axial basin infill was provided by sedimentation of shale and sandstone, whereas the rift flanks laterally supported the alluvial fan conglomerates. The tectonostratigraphic framework of the JT can be summarized as follows. Prior to basin nucleation, the first tectonic pulse generated the Coreau Dike Swarm. The subsequent pulse was able to reactivate deep Precambrian shear zones, where the Mucambo Pluton was emplaced. This was followed by mechanical subsidence, promoting basin infill (Massapê and Pacujá Fms.) in general accompanied by the emplacement of the Parapuí rocks and by volcaniclastic deposition. Next, the Meruoca Pluton intruded along the same crustal discontinuity as the preceeding one. Finally, repeated reactivation spasms in major rift faults permitted the deposition of localized alluvial fans called the AprazívelFormation. Due to the lack of subsurface investigations, the Parapuí Suite stratigraphic position on the Jaibaras column is as yet not elucidated. However, this whole igneous event appears to be composed by repeated small eruptions of mafic to intermediate magma coupled with ash-flow sheets during the main stage of basin infill and prior deposition of the Aprazivel alluvialfans. In addition, the two pulses of rift-tectonics in the JT were followed by the sedimentation of clast-supported paraconglomerates as stacked fans.

Acknowledgements Thanks are due to Petrobras-E\&P for the permission to publish. The manuscript greatly benefitted from thorough reviews by Peter Szatmari, Renaud Caby, Luiz Carlos da Silva and an anonymous reviewer. Emanuel F. Jardim de Sa and Joaquim $\mathrm{R}$. Torquato provided us with some unpublished material.

\section{References}

Almeida F.F.M., Melcher G.C., Cordani U.G., Kawashita K., Vandoros P. 1968. Radiometric age determinations from northem Brazil. Boletim da Sociedade Brasileira de Geologia, 17: 3-14.

Brito Neves B.B., Long L.L., Kawashita K., Sial A.N., Cordani U.G., Pessoa R.J.R. 1978. Estudo da geocronologia dafaixa costeira pré-cambriana do Nordeste. Recife, Unpublished CNPq final report. $14 \mathrm{p}$.

Brito Neves B.B., Vandoros P., Pessoa D.A.R., Cordani U.G. 1974. Reavaliação dos dados geocronologicos do pré-cambriano do nordeste brasileiro. In: SBG, Congresso Brageocronologicos do pre-cambriano do nordeste brasileiro.
sileiro de Geologia, 28. Porto Alegre, Anais, 6: 261-271.

Cavalcante J.C., Ferrcira C. A., Armesto R.C.G., Medeiros M.F., Ramalho R., Braun O.P.G. Baptista M.B., Cunha H.C.S. 1983. Mapa Geológico do Estado do Ceará $(1: 500,000)$. Brasilia, MMFVDNPM.
Correa J.A.M. 1997. Estudo petrográfico das rochas vulcanoclasticas da Suite Parapuí, Bacia de Jaibaras, NW do Ceará. In: SBG, Simposio de Geologia do Nordeste, 17, Fortaleza, Boletim, p. 145-149.

Costa M.J., Franca J.B., Lins C.A.C., Bacchiegga I.F., Habekost C.R., Cruz W.B. 1979. Geologia da Bacia de Jaibaras, Ceará, Piaui e Maranhão - Projeto Jaibaras. Brasilia, DNPM. Serie Geologia No 14, Seção Geologia Básica No 11. 106 p.

Cowie J.W. 1981. The Proterozoic-Phanerozoic transition and the Precambrian-Cambrian boundary. Precambrian Research, 15: 199-206.

Dalziel I.W.D. 1997. Neoproterozoic-Paleozoic geography and tectonics: Review, hypothesis, environmental speculation. Geological Society of America Bulletin, 109: $16-42$. 
Danni J.C.M. 1972. Geologia da porção sul do Grupo Jaibaras - Ceará. Revista Brasileira de Geociências, 2: 85-97.

Fetter A., Van Schmus W.R., Santos T J.S., Arthaud M. Nogueira Neto J. 1997 Geocronologia e estruturação do Estado do Ceará: NW da Provincia Borborema, NE Brasil. In: SBG, Simpósio de Geologia do Nordeste, 17, Fortaleza, Boletim, p. 3233.

Gomes J.R.C., Gatto C.M.P.P., Souza G.M.C., Luz D.S., Pires J.L., Teixeira W., França F.A.B., Cabral E.M.A., Menor E.A., Monteiro N., Barros M.J.G., Ribeiro A.G., Lima E.A., Fonseca R.A. 1981. Geologia. In: Projeto Kudambrasil, levantamentos de recursos naturais, Rio de Janeiro, MME. Vol. 23, p. 27-300, (folhas Jaguaribe/ Natal).

Gorayeb P.S.S, Abreu F. A.M. Correa J.A.M., Moura C.A.V. 1988. Relacões estratigráficas entre o granito Meruoca e a sequência Ubajara-Jaibaras. In: SBG, Congresso Braentre o granito Meruoca e a sequência Ubajara-Jai
sileiro de Geologia, 35, Belem, Anais, 6: 2678-2688.

Hackspacher P.C., Scares J.W., Petta R.A. 1988. Geologia do Grupo Ubajara - Região de Frecheirinha (CE). In: SBG, Congresso Brasileiro de Geologia, 35, Belém, Anais, 6 : 2661-2677.

Harland W.B., Armstrong R.L., Cox A.V., Craig L.E., Smith A.G., Smith D.G. 1990. A geologic time scale 1989. Avon, Cambridge University Press, 263 p.

Jardim de Sa E.F. 1994. A faixa Seridó (Provincia Borborema, NE do Brasil) e seu significado geodinâmico na cadeia brasiliana/pan-africana. (unpublished Doctorate thesis) Universidade de Brasilia, Brasilia, $804 \mathrm{p}$

Jardim de Sa E.F., Hackspacher PC., Nogueira A.M.B., Lins F.A.P.L., McReath I., Srivastava N.K., Alunos da Disciplina Geologia de Campo 11-1979,1979. Observacões sobre a estratigrafia e sequências igneas da Bacia de Jaibaras, Noroeste do Ceará. In: SBG, Simpósio de Geologia do Nordeste, 9, Natal, Boletim, p. 30-38.

Mabesoone J.M., Beurlen K., Rand H.M., Costa W.D., Manoel Filho J., Barretto P.T., Rijo L, Rodrigues J.M.S., Marinho J.M.L., Nascimento P.A.B., RochaM.A. 1971. GeL, Rodrigues J.M.S., Marinho J.M.L., Nascimento P.A.B., RochaM.A. 1971.

Mello Z.F. 1978. Evoluções finais do ciclo geotectonico Brasiliano no Nordeste Oriental. In: SBG, Congresso Brasileiro de Geologia, 30, Recife, Anais, 6: 2438-2450.

Misuzaki A.M.P. \& Saracchini F.E. 1990. Catdlogo geral de dados geocronologicos da Petrobrds. Rio de Janeiro, Petrobras/Cenpes/Divex/Setec. 24 p. (Relatorio Interne).

Nascimento D.A. \& Gava A. 1979. Novas considerações sobre a estratigrafia da Bacia Jaibara. In: SBG, Simposio de Geologia do Nordeste, 9, Natal, Boletim, p. 14-29.

Nascimento D.A., Gava A., Pires J.L., Teixeira W., Franfa F.A.B., Cabral E.M.A., Stamford Radambrasil levantamentos de recursos naturals, Rio de Janeiro, MME, Vol 21 p. 23-212 (folha Fortaleza).

Novais F.R.G., Brito Neves B.B., Kawashita K. 1979. Reconhecimento cronoestratigráfico na regiao Noroeste do Ceará. In: SBG, Simposio de Geologia do Nordeste, 9, Natal, Boletim, p. 91-110.
Oliveira D.C. 1992. Geologia do Graben de Martinopole, area de Campanario/Paula Pessoa (granja - CE), implicações na evolução litoestratigrafica e tectono-metamorfica do Noroeste do Ceará. Revista Brasileira de Geociências, 22: 143-156.

Oliveira D.C. 2000. Reavaliação da evolução tectono-magmatica do Graben de Jaibaras (Nordeste do Brasil). Acta Geologica Hispanica, in press.

Paterson S.R. \& Vernon R.H. 1995. Bursting the bubble of ballooning plutons: A return to nested diapirs emplaced by multiple processes. Geological Society of America Bullutin, 107: 1356-1380.

Prado F.S., Mendonfa J.C.G., Morais J.B.A., Medeiros M.F., Assunção P.R.S., Andrade V.A., Medeiros R.P. 1981. Geologia da regiao noroeste do Estado do Ceará - Projeto Martinopole. Brasilia, DNPM. Serie Geologia No. 23, Secao Geologia Básica jeto Martinop
No. $17.59 \mathrm{p}$.

Quadros M.L.E.S., Abreu F.A.M., Gorayeb P.S.S. 1994. Considerações sobre os ambientes deposicionais das Formações Pacujá e Aprazivel, Bacia de Jaibaras - NW do Ceará.. In: SBG, Congresso Brasileiro de Geologia, 38, Camboriu, Anais, p. 240-

Sial A.N. 1989. Petrologia, geoquimica de elementos maiores, traços, terras raras e isotopes (Sr, O, H, S) nos batolitos da Meruoca e Mucambo, Ceará, Nordeste do Brasil. Unpublished Thesis, Recife, UFPE, $284 \mathrm{p}$.

Sial A.N. \& Long L.E. 1987. Rb-Sr and oxygenn isotope study of the Meruoca and Mucambo Granites, Northeastern Brazil. Short paper of the 4th International Conference of Geochronology, Cosmochemical and Isotope Geology. USGS open file report 78-701, p. 398-400.

Sial A.N., Figueiredo M.C.H., Long L.E. 1981. Rare-earth element geochemistry of the Meruoca and Mucambo Plutons, Ceará, Northeast Brazil. Chemical Geology, 31: 271-283.

Tavares Jr. S.S., Gorayeb P.S.S., Lafon J-M. 1990. Petrografia e geocronologia Rb/Sr do feixe de diques da borda oeste do Granito de Meruoca (CE). In: Congresso Brasileiro de Geologia, 36, Natal, Anais, p. 337-338

Torquato J.R., Nogueira Neto J.A. 1996. Historiografia da região de dobramentos do Médio Coreaú. Revista Brasileira de Geociências, 26: 303-314.

Vandoros P. 1968. Um granito pós-orogênico de Sobral, Ceará. In: SBG, Congresso Brasileiro de Geologia, 22, Belo Horizonte, Anais, p 5-6.

Contribution IGC-022

Received January 26, 2000 Accepted for publication May 10, 2000 